\title{
PEMBELAJARAN PRODUKSI KANAL YOUTUBE BAGI PESERTA EKSTRA KURIKULER JURNALISTIK SEKOLAH DIAN HARAPAN TANGERAN
}

\author{
Sigit Pamungkas, S.T., M.T. \\ Universitas Pelita Harapan
}

sigit.pamungkas@uph.edu

\begin{abstract}
Abstrak
Program Studi Ilmu Komunikasi, Fakultas Ilmu Sosial dan Ilmu Politik, Unversitas Pelita Harapan bekerjasama dengan SDH Lippo Village, Tangerang mengadakan kegiatan ekstra kurikuler jurnalistik bagi para siswanya. Salah satu kegiatannya dilakukan pada periode Januari - Juli 2021 di masa penerapan kebijakan PPKM(Pemberlakuan Pembatasan Kegiatan Masyarakat) di masa pandemi covid 19. Pesertanya adalah siswa grade 10 hingga 12 atau setara Sekolah Menengah Atas (SMA). Peserta dibagikan materi tentang produksi video jurnalistik dan pengembangan kanal youtube. Materi tersebut dipilih karena di masa pandemi covid 19 ini, konten video dari platform youtube, telah menjadi salah satu media rujukan yang paling sering diakses oleh audiens millennial, termasuk siswa SMA. Materi yang diberikan meliputi pengenalan akan peran video sebagai media informasi di media sosial youtube, proses produksi video jurnalistik, hingga pembuatan kanal youtube pribadi. Kegiatan yang semestinya dilakukan secara tatap muka dan praktek lapangan ini, seluruhnya dilakukan secara daring menggunakan aplikasi video call dari Microsoft Teams secara Syncrounous. Proses ceramah daring dilakukan selama 16 kali pertemuan, dengan durasi satu jam per sesi, sedangkan untuk pengerjaan tugas produksi kanal youtube, peserta mengerjakannya dari rumah masing-masing. Tujuan dari kegiatan PKM ini, agar peserta sanggup membuat kanal youtube pribadi berisi video-video dengan penerapan kaidah-kaidah jurnalistik, dengan luaran PKM adalah kanal Youtube dari masing-masing peserta.
\end{abstract}

Kata kunci: Produksi video, video jurnalistik, youtube,

\section{PENDAHULUAN}

Sebagai salah satu perwujudan pelaksanaan Tridarma Program Studi Ilmu Komunikasi, Fakultas Ilmu Sosial dan Ilmu Politik, Unversitas Pelita Harapan bekerjasama dengan SDH(Sekolah Dian Harapan) Lippo Village, Tangerang mengadakan kegiatan ekstra kurikuler jurnalistik bagi para siswanya. Kerja sama ini telah dilakukan sejak sebelum masa pandemic Covid 19, dengan metode pelaksanaan berupa pengajaran di dalam kelas, dan praktek produksi jurnalistik di luar kelas. Namun setelah pandemi, covid 19, seluruh kegiatan dilakukan secara daring, termasuk kegiatan pada periode Januari - Juli 2021.

Kagitan ini diikuti oleh siswa-siswa dari grade 10 hingga 12, atau setara kelas 1-3 SMA. Proses pengajaran materi dilakukan secara asynchronous, yaitu menggunakan aplikasi MS Teams, sedangkan Tugas-tugas mingguan dikerjakan secara mandiri di rumah masing-masing, dengan tetap mengikuti protokol Kesehatan.

Secara umum, SDH Lippo Village membuka berbagai bidang ekstra kurrikuler, termasuk musik, komputer, dan berbagai bidang olah raga. Bidang

Teknologi Informasi dan Komunikasi 66 
ekstra kurikuler Jurnalistik Online dipercayakan kepada Program Studi(Prodi) Ilmu Komunikiasi FISIP UPH, karena memang di Prodi tersebut membuka bidang konsentrasi Broadcast Journalism, bagi mahasiswa yang berminat belajar jurnalistik.

Tema jurnalistik online dipilih, berdasar pertimbangan bahwa siswa-siswa remaja, khususnya siswa usia SMA kelas 1-3, yang setara dengan target PKM berada di usia yang rentan terhadap berbagai paparan konten media online. Sebuah penelitian(Juditha, 2018) menyatakan bahwa terdapat tiga pendekatan yang bisa digunakan untuk mengantisipasi penyebaran berita hoaks, yaitu:

1. Kelembagaan, teknologi dan literasi.

2. Pendekatan Teknologi, dengan aplikasi hoax cheker, yang bisa digunakan oleh masyarakat untuk mengecek kebenaran berita yang berindikasi hoax.

3. Pendekatan literasi, dengan gerakan anti berita hoaks ataupun sosialisasinya kepada masyarakat, mulai dari sekolah hingga masyarakat pada umumnya.

Relevan dengan temuan penelitian di atas, PKM ini juga memulai kegiatan yang berguna bukan hanya mengantisipasi penyebaran berita hoaks, namun juga mengajarkan cara memproduksi konten kredibel sesuai kaidah-kaidah jurnalistik yang akan dipublikasikan melalui akun Youtube. Di masa Pandemi Covid 19, dilaporkan bahwa jumlah pengakses konten Youtube meningkat(Bonaventure, 2020). Survei Google menunjukkan adanya peningkatan mulai April hingga Juni, doi mana jumlah pengguna yang mengharapkan pengalaman pengguna yang menyenangkan di suatu situs (web OEM) meningkat dari 21 persen menjadi 36 persen. Mengingat mekanisme dan cara kerja akun Youtube, peningkatan itu berpotensi membawa penonton untuk mengakses konten yang lain.

Konten yang diajarkan bervariasi, namun masih pada seputar online journalism. Beberapa tema di antaranya adalah, digital literacy, citizen journalism, News Values, Produksi Video Jurnalistik, dan Teknik Pembuatan Personal Youtube Channel. Sebuah penelitian(Hadi, et al, 2019)s menunjukkan bahwa seorang citizen journalist(warga biasa yang tak memiliki kemampuan jurnalistik, namun senang melakukan kegiatan jurnalistik) akan bangga, bahwa mereka menjadi saksi peristiwa yang larut dalam peristiwa itu sendiri. Implikasi dari pembelajaran jurnalistik adalah bahwa kejadian yang diberitakan dari persepektif warga adalah bentuk jurnalisme otentik. Keterlibatan warga dalam kegiatan jurnalistik di ruang redaksi melalui smartphone dan aplikasi pendukung lainnya menciptakan masyarakat yang terbuka dan demokratis.

Kemampuan memproduksi konten youtube bukan hanya berguna dalam menyebarkan konten jurnalistik. Sebuah penelitian(Simatauw, et al, 2021) menunjukkan bahwa proses belajar mengajar dengan memanfaatkan media sosial Youtube dinilai sanggup meningkatkan aktivitas siswa dan memperbesar minat belajar. Media Youtube juga banyak digunakan sebagai alternatif media edukasi di masa pembatasan sosial. Penelitian yang dilakukan di SMK Kristen Agape Patria ini menunjukkan bahwa media youtube membuat siswa maupun guru leoh menikmati konten pembelajaran. Materi terasa tidak monoton (verbal), dan tentu saja siswa menjadi lebih mandiri, karena materi dari youtube bisa diulang kapanpun siswa membutuhkannya.

Karena itu pembekalan tentang konten yang sehat sangat diperlukan bagi pembuat konten. Hal ini penting dilakukan karena demi menarik popularitas dan konten yang viral, sejumlah pengguna media sosial sengaja mengunggah konten yang kontroversial. Salah satunya adalah Denise Chariesta yang dikenal sering memamerkan kekayaannya melalui media sosial Tik-tok, serta merendahkan pihak lain yang tidak bisa memilikinya. Sebagai contoh, Denise pernah memamerkan ponsel merk Iphone miliknya dengan bangga, dan berujar seolah pemilik ponsel merk lain dianggap kurang berkelas. Akibat ujarannya tersebut, unggahan Denise Chariesta justeru membuatnya viral dan semakin popular.

Sebuah penelitian tentang Personal Digital Branding (Mubarok, 2021) menyimpulkan bahwa 
Denise memang memposisikan personal brand dirinya denagn sesuatu yang buruk. Ucapan negatifnya terbukti berhasil meningkatkan eskalasi jumlah netizen yang mengomentari tiap postingan Denise. Hal ini memunculkan adanya suasana baru dalam dimensi virtual Indonesia dengan menerapkan sikap "trash-talking", yaitu menyombongkan diri, tanpa takut pada siapapun dan hal itu membentuk citra tersendiri bagi dirinya, yang memang sombong. Fenomena ini menunjukkan bahwa personal brand seseorang tidak selalu ditunjukkan secara baik.

Fenomena "trash-talking" guna mengejar popularitas inilah yang menjadi salah satu perhatian dari tim penulis. Bahwa kemampuan memproduksi konten yang berorientasi pada popularitas tanpa mempedulikan dampak negatifnya sangatlah berbahaya, terlebih di masa pandemic Ketika media sosial menjadi salah satu rujukan utama kaum millenial. Sebuah penelitian(Pamungkas,et al, 2019) tentang kecenderungan generasi millennial dalam menentukan sikap politiknya menjelang menjelang Pemilu Presiden RI 2019 dilakukan di sebuah Sekolah Menengah Atas. Hasilnya menunjukkan bahwa informasi yang beredar di media sosial menjadi rujukan utama bagi mereka dalam menentukan sikap politiknya untuk mendukung pasangan capres tertentu. Dari temuan penelitian di atas, kaum millennial termasuk siswa SMA sangat memerlukan literasi digital. Lebih dari itu, mereka perlu dididik bukan hanya mampu untuk memilih dan memilah konten media sosial, namun juga memproduksi konten media sosial yang positif.

Personal Youtube Channel berpotensi untuk meningkatkan citra maupun menurunkan citra pemilik akunnya. Sama seperti pada kasus Denise Chariesta, konten yang kontroversial cenderung akan menjadi menarik perhatian netizen, konten itu akan mudah viral, dan berarti meningkatnya jumlah views, meski berpotensi merugikan si pemilik channel. Sebagai contoh adalah, youtuber Rahmawati Kekeyi Putri Cantika, yang meski pada satu sisi dianggap berlebihan, namun menurut sebuah penelitian(Kurniawan, Gabriella, 2020),
Kekeyi dinilai berhasil membawakan personal branding yang baik. Hal ini membuatnya berhasil mencapai profit sebesar 92 juta hingga 1,5 M rupiah.

Relevan dengan tema ekstra kurikuler Jurnalistik Online, tim penulis memberikan materi tentang News Values bagi para peserta ekstra kurikuler. Karena secara prinsip, peserta yang diajarkan teknik produksi video jurnalistik, juga harus diajarkan tentang News Values(Nilai-nilai berita). Sebagai seseorang yang mampu memproduksi konten jurnalistik, meski belum menjadi jurnalis professional, para peserta tersebut akan menjadi pembuat konten berita yang diistilahkan sebagai Citizen Journalism. Pada prinsipnya, fenomena Citizen Journalism takkan terhindarkan. Mereka adalah orang-orang yang akan dengan senang hati membuat berita update bagi komunitasnya meski tanpa dibekali pengetahuan jurnalistik yang benar. Diharapkan setelah PKM ini berakhir, para peserta akan menjadi seorang citizen journalist yang mampu memproduksi konten jurnalistik secara berkualitas.

Secara lebih spesifik, materi ekstrakurikuler dibagi menjadi dua, yaitu Produksi Video Jurnalistik dan Pembuatan Personal Youtube Channel. Pada pertemuan terakhir, peserta Ekstra Kurikuller diminta untuk memproduksi Personal Youtube Channel tersebut yang berisi kontenkonten video dengan News Values bisa mereka pertanggungjawabkan sebagai calon citizen journalist.

\section{HASIL DAN PEMBAHASAN}

\section{Pelaksanaan}

Sebagaimana telah dijelaskan sebelumnya, bahwa kegiatan ekstra kurrikuler ini dilakukan secara asynchronous menggunakan aplikas MS Teams.

Kegiatan berlangsung mulia jam 13.45 hingga 14.45 setiap hari kamis mulai 7 Januari hingga 6 Mei 2021.

Fasilitator utama pada kegiatan ini adalah penulis sendiri(Sigit Pamungkas, S.T., M.T.), dan Jumadal Simamora, S.Sos., M.Ikom. Sedangkan jumlah peserta ekstra kurikuler ada tujuh siswa. Materi yang dibagikan seharusnya berupa teori dan 
praktek. Namun karena adanya ketentuan pembatasan kegiatan sosial secara fisik, maka seluruh proses ceramah dilakukan secara synchronous menggunakan aplikasi MS Teams, sedangkan tugas-tugas praktek dilakukan di rumah masing-masing peserta.

Materi yang diberikan meliputi :

a. News Value(nilai-nilai berita), yaitu tentang faktor-faktor yang membuat sebuah berita bernilai tinggi dan diminati khalayak.

b. Three Production Phases(Fase Produksi Video), tentan proses produksi pembuatan video jurnalistik, mulai dari tahap perencanaan hingga tahap editing.

c. Penggunaan Search Engine Optimization(SEO) pada akun Youtube, yaitu fitur yang mengoptimalkan sebuah konten video sehingga memperoleh jangkauan yang lebih luas.

Namun pada tulisan ini, pembahasan akan difokuskan pada News Value dan Penggunaan SEO Youtube, karena memang kedua materi tersebutlah yang dibawakan oleh penulis. Sedangkan topik Three Production Phases disampaikan oleh fasilitator lain(Jumadal Simamora).

Peserta ditugaskan membuat sejumlah video dengan nilai-nilai jurnalistik dari kegiatan mereka seharihari. Peserta diijinkan menggunakan peralatan sederhana seperti ponsel untuk memproduksi video. Luaran dari kegiatan ini adalah kanal Youtube dari masing-masing peserta. Sebagai final project, peserta ditugaskan untuk membuat Personal Youtube Channel. Tugas dibuat secara Individu, meliputi nama channel, logo channel, tagline, banner, dan konten video. Video yang diunggah minimal 3 buah unggahan. Sebagai hasilnya, seluruh peserta berhasil membuat Personal Youtube Channel meski belum semuanya mencapai target yang diharapkan. Detail pembahasan tentang hasil luaran akan dijelaskan pada sub bab berikut ini.

\section{Hasil}

Secara umum, seluruh peserta menyelesaikan tugastugas yang telah diberikan dengan baik. Salah satu peserta yang menyelesaikan tugasnya dengan baik adalah peserta Bernama Michelle Handa Intan Handa. Kanal Youtubenya bernama " $5 \mathrm{~W} 1 \mathrm{H}$ with Michelle". Channel ini telah memiliki nama akun, banner, dan tagline seperti terlihat pada gambar 1 .
Ada tiga unggahan video jurnalistik pada channel ini sesuai dengan instruksi pada final project seperti terlihat pada gambar 2. Ketiga video yang diunggah tersebut sebelumnya telah mengalami proses revisi dan evaluasi sebelum diunggah di channel tersebut.

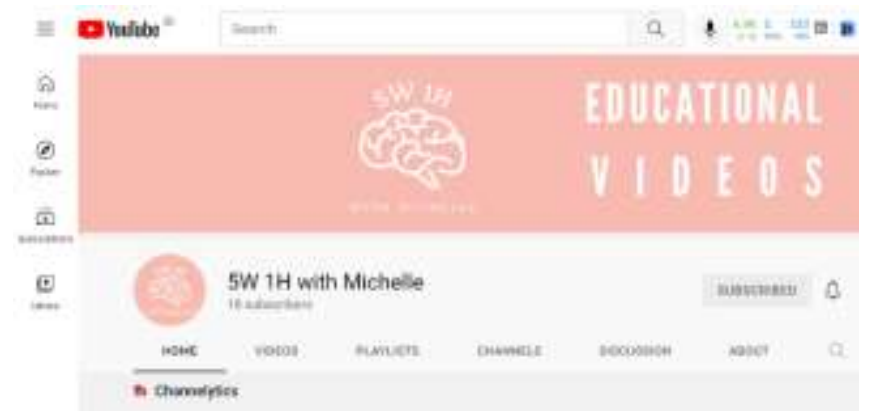

Gambar 1. Tampilan final project dari peserta Sumber : Hasil olahan pribadi

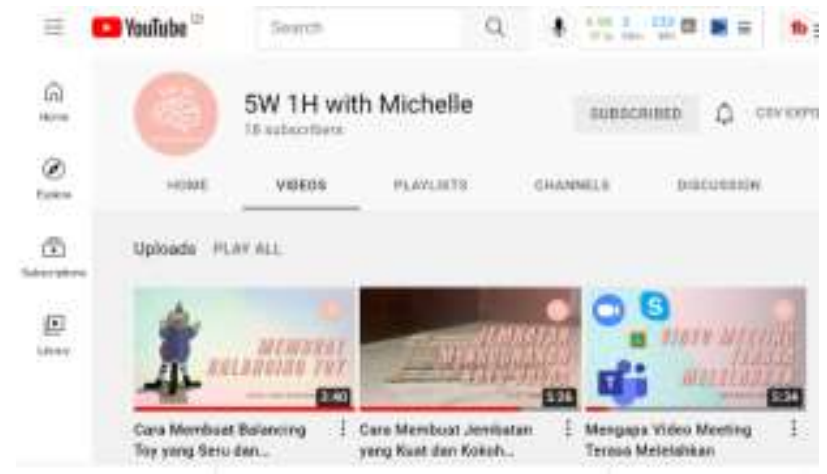

Gambar 2. Video unggahan dari akun " $5 \mathrm{~W} 1 \mathrm{H}$ with Michelle"

Sumber : Hasil olahan pribadi

Lebih detail tentang pembahasan produksi channel beserta seluruh kontennya akan dijelaskan pada sub bab pembahasan di bawah ini.

\section{Pembahasan}

Pembahasan berikut berisi analisis dari konten video ditinjau dari perspektif News Values dan SEO Youtube.

\section{a. News Values.}

News Values atau Nilai Berita(Sumadiria, 2017) adalah unsur-unsur yang membuat suatu berita memiliki konten yang menarik perhatian pengaksesnya. Nilai-nilai tersebut adalah:

1. Keluarbiasaan(Unusualness)

Teknologi Informasi dan Komunikasi 
2. Kebaruan(Newness).

3. Akibat(impact).

4. Aktualitas(Timelinese)

5. Kedekatan(Proximity)

6. Informasi(Information)

7. $\operatorname{Konflik}($ Conflict)

8. Orang Penting(Prominence)

9. Ketertarikan Manusia(human Interest)

10. Kejutan(Surprising)

11. $\operatorname{Sex}(\operatorname{Sex})$

Salah satu konten video dari channel ini yang relevan dengan konsep News Value di masa Pandemi Covid 19 adalah video berjudul "Video Meeting Terasa Melelahkan, Mengapa Demikian"

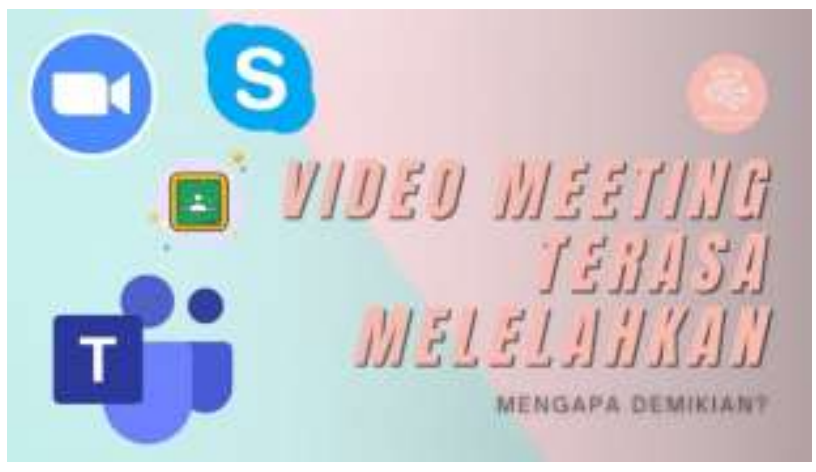

Gambar 3. Thumbnail video tentang ulasan penyebab video meeting terasa melelahkan.

Video ini berisi narasi dan illustrasi grafik yang memberikan eksplanasi tentang fenomena kelelahan yang diderita para pengguna video meeting. Gejala di atas disebut Zoom Vatigue atau Virtual Meting Vatigue. Selanjutnya video ini juga menjelaskan berbagai argumentasi dari sumber yang kredibel. Di akhir video dijelaskan juga cara mengatasi Virtual Meeting Vatigue ini yang berguna bagi siapapun yang mengalaminya.

News Values yang relevan dengan video ini antara lain Newness, karena fenomena ini relatif baru seiring dengan munculnya pandemic Covid 19. Bahkan mungkin tidak disadari oleh sebagian bsar penderitanya. Video ini juga memiliki impact bagi penggunanya, walau baru memiliki 18 subscribers, namun video ini telah mendapat 33 likes dan ditonton 105 kali. Dari sisi Timelines, video ini juga termasuk aktual, karena issue yang diangkat sedang dialami oleh sebagian besar orang di masa pandemic hingga saat ini. Video ini juga mengandung nilai information yang berguna bagi pengguna video meeting sehingga mereka bisa memahami kelelahan yang mereka hadapi.

\section{b. SEO Youtube}

SEO atau Search Engine Optimization ialah bagian yang krusial bagi sebuah brand(Youtube Channel) yang ditampilkan secara online. Mayoritas pengguna internet menggunakan search engine untuk mencari kebutuha konten mereka. 93\% traffic pada website tampil akibat adanya search engine (Schaffner, 2019). Konten teratas cenderung akan diakses oleh para pencarinya, sehingga setiap pengguna media online akan berusaha meningkatkan brand(konten) mereka pada peringkat atas search engine. Pada prinsipnya, SEO adalah fitur yang memudahkan sebuah konten ditemukan oleh pencarinya. Karena itulah pengoptimalan SEO menjadi sangat penting.

Youtube menyediakan fitur-fitur yang bisa digunakan pemilki akunnya untuk meningkatkan SEO(Ciampa et.al, 2020). Fitur-fitur itu adalah Title, Channel Description, Thumbnail, dan Tags, berikut pembahasannya:

\section{Title.}

Title adalah judul atau nama yang relevan dengan isi video. Title juga berguna untuk memudahkan fitur penonton Youtube mencari konten yang relevan dengan judul tersebut. Channel Youtube " $5 \mathrm{~W} 1 \mathrm{H}$ with Michelle" memiliki tiga unggahan video yang representatif dengan konten masingmasing video. Ketiga title tersebut adalah: a. Mengapa Video Meeting Terasa Melelahkan b. Cara Membuat Jembatan yang Kuat dan Kokoh c. Cara Membuat Balancing Toy yang Seru dan Menyenangkan.

Teknologi Informasi dan Komunikasi 70 
Implementasi dari fitur Title ini bisa dilihat pada gambar 2 di atas.

\section{Channel Description}

Channel Description adala fitur yang memberikan penjelasan konten video secara umum, meliputi deskripsi umum, topik-topik video, link pada tiap topik, dan hashtag.

Deskrkripsi umum menjelaskan tentang konten video secara keseluruhan, sehingga penonton bisa mempertimbangkan jika ingin melanjutkan menonton atau ganti mengakses channel lain. Hal ini bisa dilihat pada gambar 3 di bawah ini.

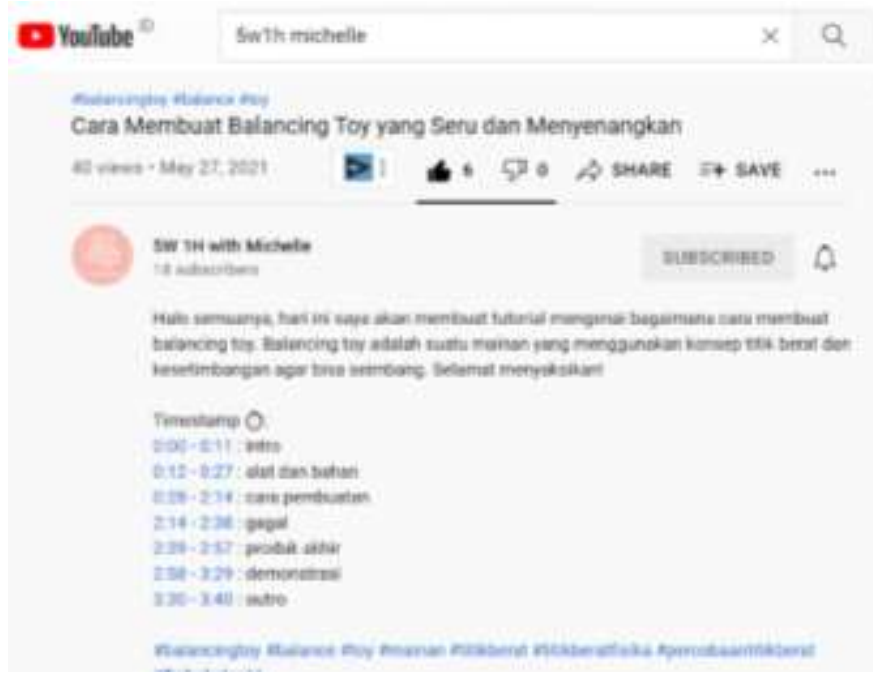

Gambar 4. Penerapan fitur Title pada salah satu judul video channel "5W1H with Michelle"

Sumber : Hasil olahan pribadi

Selain berisi deskripsi umum, fitur ini juga bisa digunakan untuk memberikan pembagian kontenkonten video berdasarkan urutan waktu. Pada gambar 3 di atas, terlihat pada detik ke 00.00 hingga detik ke 00.11, berisi "intro". Pada detik ke 00.12 hingga 00.27 , berisi "alat dan bahan", dan seterusnya. Pengakses mengklik pada angka-angka itu, sesuai dengan bahasan konten yang dikehendaki.

Fitur ini juga memungkinkan penulisan hashtag berdasar kata kunci yang relevan, yang bertujuan agar konten ini mudah ditemukan.

\section{Thumbnail}

Thumbnail adalah tampilan gambar video yang didesain untuk menarik perhatian audiens. Thumbnail berfungsi sebagai semacam cover buku. Youtube memiliki fitur pilihan Thumbnail yang bisa dibuat dengan du acara. Cara pertama, fitur ini akan secara acak memilih beberapa potongan gambar yang diambil dari bagian video tersebut. Cara ini dianggap kurang menarik, karena tampilan visual dipilih secara acak oleh fitur ini, sehingga adegan yang dipilih belum tentu memiliki daya tarik. Cara kedua adalah dengan mendesain sendiri Thumbnail tersebut menggunakan software grafis. Dengan cara ke dua ini, Thumbnail bisa didesain sedemikian rupa sesuai selera pemilik channel. Judul pada Thumbnail bisa dibuat berbeda dengan judul pada title, seperti terlihat pada gambar 2. Bahkan bisa ditambahkan dengan elemen grafik yang tidak ada di dalam video.

Channel "5W1H with Michelle" telah memanfaatkan fitur ini sebagaimana mestinya.

\section{Tags}

Fitur Tags memungkinkan suatu video dikelompokkan berdasar kata kunci yang paling sring di cari. Secara prinsip, fungsi Tags adalah sama dengan fungsi hashtag pada berbagai platform media sosial yang lain, bedanhya, penggunaan fitur berada di dalam setting masing-masing video, sehingga kata kunci pada fitur Tags tidak akan terlihat oleh audiens. Hanya pemilik channel saja yang bisa mengakses fitur tersebut. Penulis tidak memiliki akses akun yang diteliti. Contoh pada gambar 4 menunjukkan penggunaan fitur Tags milik channel penulis.

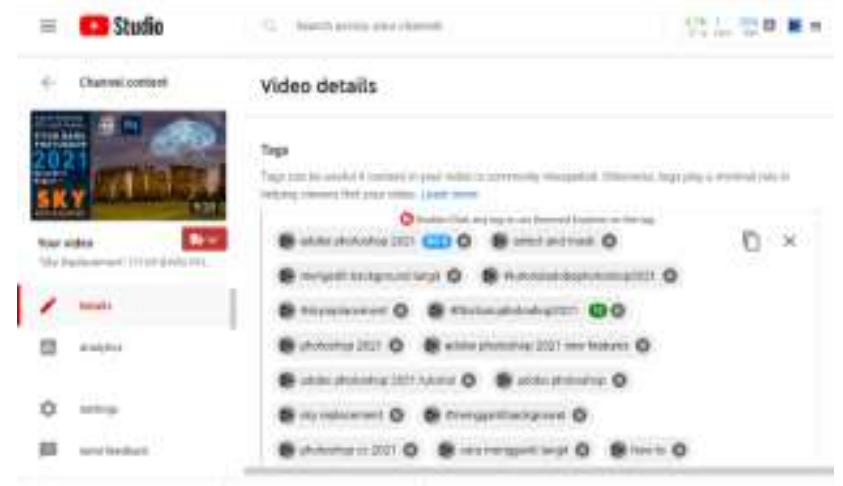

Teknologi Informasi dan Komunikasi 71 
Gambar 5. Contoh penerapan fitur Tag dengan kata kunci seputar tutorial Adobe Photoshop.

Sumber : Hasil olahan pribadi

Secara umum, channel dari peserta lain juga menampilkan video yang kontennya dibuat berdasarkan pendekatan News Value serta memanfaatkan fitur SEO Youtube. Hal ini menunjukkan bahwa peserta ekstra kurikuler SDH Lippo Village mampu memproduksi konten video Youtube yang bersifat positif. Kegiatan PKM ekstra kurikuler ini memiliki sutainibility karena masih berlanjut hingga saat ini tulisan ini dibuat, dengan topik yang berbeda. Harapan penulis, kiranya PKM produksi video jurnalistik ini mampu mendorong para peserta, khususnya generasi millennial agar mengisi media sosial berplatform video dengan konten positif.

\section{KESIMPULAN}

Di tengah maraknya berbagai konten negatif, berupa hoaks, disinformasi, hate speech, dan konten negatif lainnya, generasi millenial yang menjadi peserta ekstra kurikuler Jurnalistik Online mampu membedakan konten negatif dan positif berdasar materi yang telah diberikan. Merujuk pada konten video yang telah dibuat, ara peserta juga dinilai mampu memproduksi konten-konten positif yang bisa dipertanggungjawabkan sesuai dengan kaidah-kaidah News Value sebagai mana disampaikan oleh Haris Sumadiria. Para peserta juga mampu mengoptimalkan keempat fitur SEO Youtube termasuk fitur Thumbnail. Kemampuan menggunakan fitur Thumbnail menunjukkan tingkat keseriusan para peserta, karena effort untuk membuat Thumbail, membutuhkan keterampilan olah desain digital, menggunakan software grafis(Adobe Photoshop dan Adobe Illustrator). Padahahal keterampilan tersebut bukan merupakan bagian PKM ini. meskipun belum viral ataupun belum memperoleh jumlah view yang banyak. Pada akhirnya peran Personal Youtube Channel milik peserta ini sangat penting guna mengimbangi konten-konten negatif yang beredar di masa pandemi.

\section{UCAPAN TERIMAKASIH}

Terimakasih kami ucapkan kepada Marsefio Luhukay S.Sos., M.Ikom., selaku Kaprodi Ilmu Komunikas FISIP UPH dan Pimpinan Sekolah Dian Harapan yang telah memberi kesempatan kepada penulis untuk melakukan kegiatan PKM ini. Terimakasih juga kami ucapkan kepada Sakundiningtiasari, M.Pd., selaku coordinator kegiatan Ekstra Kurikuler Sekolah Dian Harapan.

\section{REFERENSI}

Bonaventure, Lionel. November 2020. Waktu Tonton YouTube Meningkat di Masa Pandemi. Diakses pada 3 Maret 2021 dari https://mediaindonesia.com/read/detail/33680 7-waktu-tonton-youtube-meningkat-di-masapandemi

Ciampa, Rob. Ciampa, Matt. Go, Theresa. Murphy, Rich.(2020). Youtube Channels for Dummies. $2^{\text {nd }}$ Edition. John Wiley \& Sons, Inc. Canada.

Juditha, Christiany.(2018). Interaksi Komunikasi Hoax di Media Sosial serta Antisipasinya Hoax Communication Interactivity in Social Media and Anticipation. Jurnal Perkomas., Vol.3. No.1. April 2018.

Kurniawan, Nadialista. Gabriella , Sonia. (2020) Personal Branding Sebagai Komodifikasi Konten Pada Akun Youtube Rahmawati Kekeyi Putri Cantika. Diakses pada 23 September 2021 dari : https://jurnalintelektiva.com/index.php/jurnal /article/view/251

I. P. Hadi, A. Setiawan, D. Yoanita and A. I. Aritonang, "The Meaning of Sharing Information in Citizen Journalism," 2019 4th Technology Innovation Management and Engineering Science International Conference (TIMES-iCON), 2019, pp. 1-5, doi: $\quad$ 10.1109/TIMESiCON47539.2019.9024371

Mubarok, Muhamad Husni.(2021). Perseteruan Denise dan Uya Kuya: Trash-Talking Sebagai Personal Digital Branding. Diakses

Teknologi Informasi dan Komunikasi 72 
pada 26 September 2021, dari : http://repository.ubharajaya.ac.id/10750/1/il ovepdf merged\%20JSC\%20artikel.pdf

Pamungkas, Sigit. Wardaningsih, Agustin.D., Simorangkir, Deborah N.(2019). "Generaksi.org", a Media and Politics Literacy Platform for Indonesia's First-time Voter. Diakses pada 28 September 2021, dari : https://eudl.eu/doi/10.4108/eai.16-102019.2304330.

Simatauw, Marfy. Tutul, Tuleka. (2021) Manfaat Penggunaan Media Sosial Youtube sebagai Media Pembelajaran Pendidikan Agama Kristen di SMK Kristen Agape Patria, Sosok. Diakses dari http://sttborneo.ac.id/ejournal/index.php/ichtus/article/view/13/8, pada 28 Agustus 2021.

Sumadiria, Haris. (2017). Jurnalistik Indonesia: Menulis Berita dan Feature, Panduan Praktis Jurnalis Professional. Simbiosa Rekatama Media.

Schaffner, Adam.(2019). Social Media Marketing Workbook \#2019-2020: How to Leverage The Power of Facebook Advertising, Instagram Marketing, YouTube and SEO To Explode Your Business and Personal Brand. Social Media Guru. 